\title{
RENEWING THE MIND \\ The Role of COGNITION LANGUAGE \\ IN PAULINE THEOLOGY AND ETHICS ${ }^{1}$
}

\section{Lee S. Bond}

The main purpose of this thesis is to examine the role of cognition language within Paul's theological and ethical arguments. I begin my study with questions concerning Paul's concept of mind renewal and how this topic relates to both his theology and his ethics. Romans 12:2 is one of the most well known and often quoted verses in all of the New Testament: Do not be conformed to the pattern of this world, but be transformed by the renewal of your mind. Käsemann and others have noted that 12:2 is part of a bridging passage that links Paul's doctrinal statements of the previous eleven chapters with the ethical exhortations of chapters 12-16. As such, the verse stands at the centre of Paul's theology and ethics. Nevertheless, there is a problem with how the admonitions Paul delivers in Romans 12-16 follow from and/or are integral to the theological claims of Romans 1-11. I found the proposed solutions to this problem unsatisfactory. Thus, my study challenges the way scholars have traditionally understood the relationship between Paul's theology and ethics, while at the same time offering a new proposal. I argue that Paul uses cognition language to link his theological propositions to his ethical admonitions. Moreover, the apostle's ethical exhortations were directly based on the message and known character of Christ which Paul proclaimed. In short, the thesis explores Paul's understanding of the relationship between the work of Christ, the human mind, and the will. The study has two distinct, yet interrelated objectives.

My main objective is to explore Paul's concept of mind renewal by

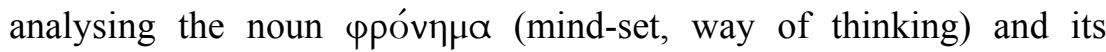
cognates within Romans and Philippians. Within all of Paul's letters,

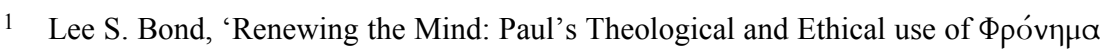
and Cognates in Romans and Philippians' (Ph.D. dissertation, University of Aberdeen, 2005). Supervisor: Dr A. D. Clarke. 
but especially in Romans and Philippians, Paul consistently employs language associated with human cognition or reasoning. I demonstrate

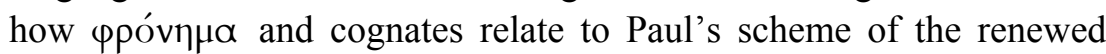
mind in these letters.

My second objective is to explore how the apostle employs cognition language to link his theology with his ethics. How these two dimensions of Paul's gospel relate to one another has been a source of

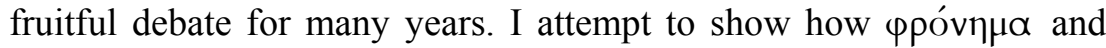
cognates serve as a kind of lexical bridge, spanning the gap between Paul's theology and ethics. I explore how the narrative substructure of the life of Christ (his character and attitude) provide Paul with a primary source for his scheme of the renewed mind. By examining the theological and ethical settings in which the word group is found, I was able to see how the apostle's theology and ethics were related. I then moved towards a better understanding of his scheme of the renewed mind.

The procedure for word study offered here is the one outlined by James Barr and modified by J. P. Louw, M. Silva and others. According to these authors, the meaning of any given word is influenced by its surrounding context. Thus, the overriding interpretive principle that governs this study is that the sentence or speech-act constitutes the basic unit of meaning. The meaning of a word thus depends not on what it is in and of itself, but on its relation to other words and to other sentences which form its context.

This exegetical-contextual interpretation of $\varphi \rho o ́ v \eta \mu \alpha$ and its cognates then becomes the foundation upon which subsequent theological and ethical interpretation builds. In so doing, it is therefore possible to avoid forcing the terms into the researcher's personal preconceived paradigm.

In my study, I explore the specific theological and paraenetic settings in which the word group appears. The terms, along with their immediate and broader contexts are subjected to rigorous historical and contextual analysis, including such matters as the history of interpretation, vocabulary, style, syntax, and textual criticism (where necessary). I allow the terms, as illuminated and defined by their contextual settings, to delineate the role they played in the theological and ethical arguments of Paul.

Chapters 1-2: Introduction and Overview. A necessary prelude to the study of 
word group is used in secular Greek, Septuagintal Greek and the nonPauline literature of the NT. Although Paul employs the word group in a unique way, giving it theological and ethical significance, $\varphi \rho o ́ v \eta \mu \alpha$ and cognates have a previous history. The word group already possessed a generally accepted range of meaning. I therefore explore the meaning of the $\varphi \rho \eta \dot{~}$ (understanding, way of thinking) termini group in Classical Greek, the Greek of the LXX, and the rest of the NT.

Chapter 3: Cognition Language in Romans. Here I examine Paul's

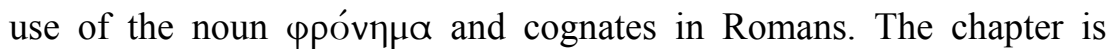
divided into three main sections: The first section contains certain introductory background matters that are directly relevant to the study (Section 3:0). Because Paul employs the cognate group in the course of dealing with specific community problems, I devote considerable attention to the possible historical exigencies that may have prompted the letter in the first place. The section also touches on the main theme of the letter and how Paul's scheme of the renewed mind relates to that main theme of obedience and faith. Section 3:1 explores the theological foundations that undergird Paul's scheme of the renewed mind. Here, I show how the exhortation in Romans 12:2 is lexically and semantically tied to the theological arguments of chapters $1-11$. I argue that $12: 2$ is illuminated by Paul's use of cognition language in $1: 18-32 ; 5: 1-8: 30$, and 11:17-25. The discussion of theological foundations is divided into four main sections: Christological (3:1:2), pneumatological $(3: 1: 3)$, transformational (3:1:4), and future eschatological (3:1:5).

The second half of chapter 3 explores Paul's use of the cognate group in the ethical arguments of chapters 12-16 (3:2). I begin this section with some preliminary comments about the ethnic composition of the community, the possible source of disunity and the material basis for the apostle's ethical exhortations. I then move on to exegete those particular passages where the word group appears. Overall, I show how the ethical exhortations of these later chapters develop out of, and are based upon the theological presuppositions of the earlier chapters. I likewise show how Paul's knowledge of the Jesus Tradition influences his concept of mind renewal.

Chapter 4: Cognition Language in Philippians. In this chapter, I examine how Paul employs cognition language to link his theology with his ethics in Philippians. While I do study all cognition terms within the letter, I give focused attention to the apostle's use of the verb ppovéw (thinking, to have an attitude or frame of mind). Although 
scholars have noted the relative importance of this term in Philippians, my study breaks new ground in showing how Paul uses it to link his theology with his ethics. This chapter is structured in a similar manner to chapter 3, having three main sections. I begin with some introductory statements about the historical situation and I discuss the thematic significance of $\varphi \rho o v \varepsilon ́ \omega$ (4:0). I then move on to explore how Paul uses $\varphi \rho o v \varepsilon ́ \omega$ within his theological (4:1) and ethical arguments $(4: 2)$.

Chapter 5: Study Results. The results of my work are summarised in chapter 5 and implications are drawn from Paul's theological and ethical use of the $\varphi$ póvๆ $\mu \alpha$ cognate group. In short, I have attempted to give a synthetic account of the apostle's scheme of the renewed mind. This synthetic account is based primarily on the apostle's theological and ethical use of $\varphi \rho o ́ v \eta \mu \alpha$ and cognates in Romans and Philippians.

The concept of mind renewal may be summarised as follows: According to Paul, believers are to reason theologically. The God who restores the mind through the work of Christ, empowers believers to reason in a renewed, theological way. Believers are therefore encouraged to reflect deeply on the work of Christ, the Spirit, sanctification, and the coming eschaton. Secondly, believers likewise encouraged to reason Christocentrically. Within the paraenetic sections of Romans and Philippians, Paul encourages believers to pattern their thinking and subsequent conduct after Christ's thinking and conduct. Thus, Paul's theology and ethics are intimately tied together by way of cognition language. According to the apostle, as believers engage in the process of theological and ethical reflection, their minds are transformed and restored by means of the Spirit of God. My conclusions run contrary to those who suggest that Paul had no real ethical theory and no rational standard for the believer's conduct. After examining the evidence, I found that Paul's ethical exhortations were primarily based on his knowledge of the person of Jesus (i.e. The Jesus Tradition). Thus, Paul's theology and ethics are seamlessly tied together by way of cognition language.

The study contains three appendices: Appendix A indicates all cognition terms discussed in the body of the study. Appendix B is a detailed exegesis of Romans 8:5-8. Appendix $\mathrm{C}$ discusses the debate surrounding the structure of Romans 5-8. 